American Journal of Agricultural and Biological Sciences 4 (1): 63-71, 2009

ISSN 1557-4989

(C) 2009 Science Publications

\title{
Chemical and Physical Characteristics of Cocopeat-Based Media Mixtures and Their Effects on the Growth and Development of Celosia cristata
}

\author{
Yahya Awang, Anieza Shazmi Shaharom, Rosli B. Mohamad and Ahmad Selamat \\ Department of Crop Science, Faculty of Agriculture, University Putra Malaysia, \\ 43400 UPM Serdang, Selangor, Malaysia
}

\begin{abstract}
Problem statement: Cocopeat is considered as a good growing media component with acceptable $\mathrm{pH}$, electrical conductivity and other chemical attributes but it has been recognized to have high water holding capacity which causes poor air-water relationship, leading to low aeration within the medium, thus affecting the oxygen diffusion to the roots. Incorporation of coarser materials into cocopeat could improve the aeration status of the media. Approach: Selected chemical and physical characteristics of five types of growing media comprising of (v/v) 100\% cocopeat, 70\% cocopeat: $30 \%$ burnt rice hull, $70 \%$ cocopeat: $30 \%$ perlite, $70 \%$ cocopeat: $30 \%$ kenaf core fiber and $40 \%$ cocopeat: $60 \%$ kenaf core fiber were determined and their suitability as growing media was tested using Celosia cristata. Data on $\mathrm{pH}$, Electrical Conductivity (EC) and various aspects of air-water relationships of the media, as well on growth and flowering of test plant and leaf nutrient contents were collected. Results: Initial $\mathrm{pH}$ for 100\% cocopeat and 70\% cocopeat: $30 \%$ kenaf core fiber was higher than the other media but the values were eventually similar by the end of the study. The bulk density and EC of media containing burnt rice hull was markedly higher than the other media $\left(0.12 \mathrm{~g} \mathrm{~cm}^{3}\right.$ and $0.48 \mathrm{mS} \mathrm{cm}^{-1}$, respectively). Media comprising of $70 \%$ cocopeat: $30 \%$ burnt rice hull and $70 \%$ cocopeat: $30 \%$ perlite contained higher air content. The former held the highest volume of available water. Incorporation of burnt rice hull and perlite into cocopeat increased water absorption ability of the media which reached saturation earlier than the other media. Addition of burnt rice hull (30\%), perlite (30\%) and kenaf core fiber (30\%) to cocopeat elevated the Air-Filled Porosity (AFP) of the media. The growth and flowering of Celosia cristata were the greatest when grown in a mixture of $70 \%$ cocopeat: $30 \%$ burnt rice hull and perhaps linked with a good balance in the aeration and moisture relationship of the media. Conclusion: Results of this study indicated that certain chemical and physical properties of cocopeat can be improved through incorporation of burnt rice hull and its positive effect was clearly reflected in the growth and development of Celosia cristata.
\end{abstract}

Key words: Coconut coir dust, burnt rice hull, kenaf core fiber, perlite, growing media, annual flowers

\section{INTRODUCTION}

Use of suitable growing media or substrates is essential for production of quality horticultural crops. It directly affects the development and later maintenance of the extensive functional rooting system. A good growing medium would provides sufficient anchorage or support to the plant, serves as reservoir for nutrients and water, allow oxygen diffusion to the roots and permit gaseous exchange between the roots and atmosphere outside the root substrate ${ }^{[1-3,7,18]}$. Top soil is used as a part of growing medium by many nurserymen. It is a non-renewable resource. Increasing utilization of available land for physical and infrastructural development rapidly declines the supply of quality topsoil and thus promoting the utilization of soilless materials in the production of horticultural crops.
One of the soilless materials widely available in the tropics is the coconut coir dust or commercially known as cocopeat. Cocopeat is an agricultural by-product obtained after the extraction of fiber from the coconut husk $^{[1]}$. As a growing medium, cocopeat can be used to produce a number of crop species with acceptable quality in the tropics ${ }^{[28,29]}$. Cocopeat is considered as a good growing media component with acceptable $\mathrm{pH}$, electrical conductivity and other chemical attributes ${ }^{[1]}$. However, cocopeat has been recognized to have high water holding capacity which causes poor air-water relationship, leading to low aeration within the medium, thus affecting the oxygen diffusion to the roots. Physical properties of cocopeat is highly dependent on it processing technique and handling ${ }^{[1]}$ and the air capacity and water retention of the material may vary from 11-53 and from 50-81\% respectively.

Corresponding Author: Yahya Awang, Department of Crop Science, Faculty of Agriculture, University Putra Malaysia, 43400 UPM Serdang, Selangor Tel: +603-89466917 
Incorporation of coarser materials into cocopeat could improve the aeration status of the media ${ }^{[7,18,20]}$. Burnt rice hull, kenaf core fiber and perlite are among the possible coarser materials could be used to improve the air-water relationship of cocopeat ${ }^{[10,20,22]}$. Raw rice hull has low water-holding capacity and high pore space. Rice hull has been used as a substitute for organic or inorganic components to replace vermiculite and perlite and was reported to be effective in improving drainage or aeration of the growing media ${ }^{[22]}$. Rice hull is often incinerated to form fine charcoal-like dust. When use as a component for growing media, this substance might behave like fine sand, except it is lighter and may content some nutritional elements and sterile. Kenaf core fiber which can be developed as a peat alternative was found to be a suitable constituent of growth media for a wide range of fast-growing ornamental and vegetable plant species ${ }^{[17]}$. On the other hand, perlite is recognized to have a unique capillary action make it superior growing media for hydroponic cultures ${ }^{[19]}$. It is very useful for increasing aeration and drainage within the container because of its uniformity and lightness. Perlite possess tiny cavities covering the surface of each particle. These cavities provide aeration and extremely large surface area which could hold moisture and nutrients that make them available to plant roots. In addition, because of the physical shape of particle, air passages are formed, providing a fine balance between moisture retention and aeration. Addition of cocopeat into perlite enhanced the growth and productivity of gerbera $^{[16]}$.

The possibility of combining different components of these soilless materials (burnt rice hull, kenaf core fiber and perlite) with cocopeat to be used as growing media was examined in this study. Thus, the objectives of the study are to characterize the chemical and physical characteristics of various combinations of cocopeat with soilless materials and determine their possible effects on the leaf nutrient status, growth and flowering of Celosia cristata.

\section{MATERIALS AND METHODS}

Plant materials and experimental treatments: This study was carried out at agro-technology unit, university Agriculture Park, University Putra Malaysia, Serdang, Selangor, Malaysia. The treatments consisted of five different combinations of growing media using cocopeat, burnt rice hull, perlite and kenaf core fiber (v/v basis): $100 \%$ cocopeat $\left(\mathrm{T}_{1}\right), 70 \%$ cocopeat , i.e., $30 \%$ burnt rice hull $\left(\mathrm{T}_{2}\right), 70 \%$ cocopeat: $30 \%$ perlite $\left(\mathrm{T}_{3}\right), 70 \%$ cocopeat: $30 \%$ kenaf core fiber $\left(\mathrm{T}_{4}\right)$ and $40 \%$ cocopeat: $60 \%$ kenaf core fiber $\left(\mathrm{T}_{5}\right)$. As the mixture is expected to have low inherent status of plant nutrients,
$5.0 \mathrm{~g}$ of slow release fertilizer (Agroblen ${ }^{\circledR}, 17 \mathrm{~N}$ : $8 \mathrm{P}_{2} \mathrm{O}_{5}$ : $9 \mathrm{~K}_{2} \mathrm{O}: 3 \mathrm{MgO}$ ) and $2.0 \mathrm{~g}$ of ground magnesium limestone (GML) were incorporated in every liter of media during the preparation.

Celosia cristata cv. Kurume Gold (Takii and Co. Ltd., Kyoto, Japan), an annual flower was used as the indicator plant. The plants were germinated and raised in plug trays (406 cells/tray) containing $40 \%$ cocopeat, $40 \%$ burnt rice husks and $20 \%$ sand medium incorporated with $5.0 \mathrm{~g}$ of a slow release fertilizer (Agroblen®, $17 \mathrm{~N}: 8 \mathrm{P}_{2} \mathrm{O}_{5}: 9 \mathrm{~K}_{2} \mathrm{O}: 3 \mathrm{MgO}$ ) and $2 \mathrm{~g}$ of GML L ${ }^{-1}$. The seedlings were raised in a rainshelter and watered twice daily. At day 12 (when the seedlings were about $2 \mathrm{~cm}$ in height with 3-4 true leaves), the plants were transplanted into $15 \mathrm{~cm}$ pots containing the respective growing media. The seedlings were watered manually twice daily $\left(250 \mathrm{~mL} \mathrm{plant}^{-1}\right)$. The plants were sprayed with a complete foliar fertilizer containing $\left(\mathrm{mg} \mathrm{L}^{-1}\right) 232 \mathrm{~N}, 67 \mathrm{P}, 239 \mathrm{~K}, 120 \mathrm{Ca}, 30 \mathrm{Mg}, 3 \mathrm{Fe}, 0.62$ Mn, 0.44 B, 0.02 Cu, 0.11 Zn and 0.048 Mo (IMPRA ${ }^{\circledR}$, Mega Prima Resources Sdn Bhd., Shah Alam, Selangor, Malaysia) together with $0.71 \mathrm{~g} \mathrm{Ca}\left(\mathrm{NO}_{3}\right)_{2} .4 \mathrm{H}_{2} \mathrm{O} / \mathrm{L}$ at a weekly interval.

\section{Data collection:}

Properties of growing media: The properties of growing media were determined for factors known to affect plant growth. These were the $\mathrm{pH}$ and EC, bulk density, water retention capacity, wettability and airfilled porosity. Media samples were taken accordingly after preparation and then put to specific determination of the properties.

pH and electrical conductivity: The $\mathrm{pH}$ values for all media before and after planting were determined by mixing $10 \mathrm{~g}$ of media with $50 \mathrm{~mL}$ distilled water, agitated for $30 \mathrm{~min}$ and left standing for $24 \mathrm{~h}$. For determination of EC, $40 \mathrm{~g}$ of media was mixed with $80 \mathrm{~mL}$ distilled water, shaken for $15 \mathrm{~min}$ and left for $60 \mathrm{~min}$. The mixtures were filtered before the measurements were made using a $\mathrm{pH}$ meter (Mettler Toledo, Model MP 220) and EC meter (MeterLab, Model CDM 210). Only initial EC was determined in the study.

Bulk density: Evaluation of bulk density was done by using the core method ${ }^{[21]}$. The media in the core ring were saturated by allowing water to diffuse into the media for two days. After recording their weights, the samples were oven-dried at $105^{\circ} \mathrm{C}$ for $24 \mathrm{~h}$. The bulk density $\left(\rho_{b}\right)$ was calculated using the formula $\rho_{b}=W_{b^{-}}$ $\mathrm{Wr} /(\pi \mathrm{h} \mathrm{d} / 4)$, where $\mathrm{W}_{\mathrm{b}}$ is the weight of the media and core-ring after oven-drying $(\mathrm{g}), \mathrm{W}_{\mathrm{r}}$ is the weight of the 
core ring $(\mathrm{g}), \mathrm{h}$ is the core ring height $(\mathrm{cm})$ and $\mathrm{d}$ is the core ring diameter $(\mathrm{cm})$.

Water retention: Water retention of the media was measured using a pressure chamber and the pressure plate $^{[21]}$. Ten grams of fresh medium was placed in a retaining ring. The sample was saturated for $24 \mathrm{~h}$ by keeping the water level just below the edge of the ring in a tray. The plates with media sample were then placed inside the corresponding pressure chamber connected to an outflow tube. Different levels of pressure were applied on each sample. The samples were taken out when there were no dripping detected. The samples were then weighted and oven-dried for $24 \mathrm{~h}$ and their dry weights recorded. The curves of volumetric water content over the soil suction were plotted.

Wettability: Medium wetability was measured by soaking the pots filled with $1 \mathrm{~L}$ of oven dried media (without plant) in standing water of $2 \mathrm{~cm}$ deep in plastic trays $^{[28]}$. The level of water was maintained by adding more water into the trays to ensure sufficient water is available to wet the media. The degree of wettability was monitored hourly for $6 \mathrm{~h}$ by weighing the media using an electronic balance. To avoid loss of water through dripping during weighing process, the pots were placed on paper plates and water collected in the plates was poured back into the pots before taking the reading. The increase in moisture content with time was calculated by subtracting the wet weight of the media with its dry weight and curves showing the changing trend in medium wettability with time were plotted.

Air-filled porosity: Air-Filled Porosity (AFP) was determined using saturation and drainage method at 2 and $5 \mathrm{~h}$ after saturation ${ }^{[28]}$. The pots, filled with $1 \mathrm{~L}$ of the respective medium (without plants), were subirrigated by immersing them into the water. The medium was considered saturated when the water has appeared on the surface. The saturated medium was removed quickly to a funnel with a $500 \mathrm{~mL}$ graduated cylinder underneath. The volume of water drained from the pot was supposed to be replaced by an equivalent volume of air and therefore the volume of water collected represents the amount of air diffused into the media. The percentage of AFP was calculated by dividing the volume of water collected with the volume of the media.

Plant growth and flowering: The effect of media on plant development was evaluated by taking various growth and flowering parameters at the end of the study (42 days after transplanting), i.e., plant height, canopy diameter, number of leaves, leaf area, time to flowering and flower length and the dry weights of stem, leaves, roots and flowers. The plant height was measured from the medium line to the top of the plants while the diameter of the canopy was measured at the widest diameter from one tip to another tip of leaves on the opposite sides of the plant. The date to flower emergence for each plant was recorded as the flower bud reached to a size of about $0.25 \mathrm{~cm}$ and their time to the first visible bud was calculated. The length of flower was determined by measuring the length from the base to its top. All intact leaves were counted and area was determined using an automatic leaf area (MODEL LI-300, LI-COR). After harvest, the leaf, stem, root and flowers were excised, dried in an oven at $80^{\circ} \mathrm{C}$ for $72 \mathrm{~h}$ and their dry weights were determined.

Leaf nutrient contents: The concentration of Nitrogen $(\mathrm{N})$, Phosphorus (P), Potassium (K), Calcium (Ca) and Magnesium $(\mathrm{Mg})$ in finely ground dried leaves were determined. About $0.25 \mathrm{~g}$ of medium sample was digested in $5 \mathrm{~mL}$ of sulfuric acid $\left(\mathrm{H}_{2} \mathrm{SO}_{4}\right)$ on hot plate at $450^{\circ} \mathrm{C}$ in a fume chamber for $7 \mathrm{~min}$. Ten $\mathrm{mL}$ of hydrogen peroxide $\left(\mathrm{H}_{2} \mathrm{O}_{2}\right)$ was then added into the mixtures and the heating continued for another four min. After the solutions were made up to $100 \mathrm{~mL}$ with distilled water and filtered, $\mathrm{N}$ and $\mathrm{P}$ contents were determined using an auto-analyzer (LACHART Instruments, Model Quikchem IC + FIA 8000 Series) while $\mathrm{K}, \mathrm{Ca}$ and $\mathrm{Mg}$ were measured using an atomic absorption spectrophotometer (Perkin Elmer, Model AAS 3110).

Experimental design and data analysis: The study was conducted in a completely randomized block design with four replications. For determination of plant growth and flowering parameters, each plot comprised of six plants. Analysis of Variance (ANOVA) on data obtained was performed using Statistical Analysis System (SAS 9.1, SAS Institute, Inc. Cary NC. USA). Least Significant Different (LSD) test at $\mathrm{p}<0.05$ was employed for mean comparison. Data on the medium wettability were subjected to non-linear regression using a function of $\mathrm{y}=\mathrm{A}\left(1-\mathrm{e}^{-\mathrm{bx}}\right)$ where $\mathrm{A}$ is asymptotic, $\mathrm{b}$ is a constant and $\mathrm{e}=2.71$.

\section{RESULTS AND DISCUSSION}

\section{Properties of growing media:}

pH and electrical conductivity: The initial $\mathrm{pH}$ and EC of the media are two important properties of any growing media as these parameters directly influenced the availability and indicate inherent nutrient status in the media, respectively. Variations in composition of the media markedly affected the initial $\mathrm{pH}$ and $\mathrm{EC}$ values of the media (Table 1). 
Am. J. Agri. \& Biol. Sci., 4 (1): 63-71, 2009

Table 1: $\mathrm{pH}, \mathrm{EC}$ values and bulk density of media mixtures

\begin{tabular}{|c|c|c|c|c|}
\hline Media (\%) & $\begin{array}{l}\mathrm{pH} \text { before } \\
\text { cultivation }\end{array}$ & $\begin{array}{l}\mathrm{pH} \text { after } \\
\text { cultivation }\end{array}$ & $\begin{array}{l}\mathrm{EC} \\
\left(\mathrm{mS} \mathrm{cm}^{-1}\right)\end{array}$ & $\begin{array}{l}\text { Bulk } \\
\text { density } \\
\left(\mathrm{g} \mathrm{cm}^{-3}\right)\end{array}$ \\
\hline$\overline{100 \text { cocopeat }\left(T_{1}\right)}$ & $6.6 \mathrm{a}$ & $4.4 \mathrm{a}$ & $0.16 \mathrm{c}$ & $0.07 \mathrm{~b}$ \\
\hline $\begin{array}{l}70 \text { cocopeat: } 30 \text { burnt } \\
\text { rice hull }\left(\mathrm{T}_{2}\right)\end{array}$ & $4.7 \mathrm{c}$ & $4.4 \mathrm{a}$ & $0.48 \mathrm{a}$ & $0.12 \mathrm{a}$ \\
\hline 70 cocopeat: 30 perlite $\left(T_{3}\right)$ & $6.2 \mathrm{~b}$ & $4.4 \mathrm{a}$ & $0.21 \mathrm{~b}$ & $0.05 \mathrm{~b}$ \\
\hline $\begin{array}{l}70 \text { cocopeat: } 30 \text { kenaf core } \\
\text { fiber }\left(\mathrm{T}_{4}\right)\end{array}$ & $6.6 \mathrm{a}$ & $4.5 \mathrm{a}$ & $0.14 \mathrm{~d}$ & $0.06 \mathrm{~b}$ \\
\hline $\begin{array}{l}40 \text { cocopeat: } 60 \text { kenaf core } \\
\text { fiber }\left(\mathrm{T}_{5}\right)\end{array}$ & $6.0 \mathrm{~b}$ & $4.7 \mathrm{a}$ & $0.14 \mathrm{~d}$ & $0.07 \mathrm{~b}$ \\
\hline $\mathrm{LSD}_{0.05}$ & 0.21 & 0.28 & 0.01 & 0.026 \\
\hline
\end{tabular}

The $\mathrm{pH}$ of $\mathrm{T}_{1}$ and $\mathrm{T}_{4}$ were higher than those of the other media $(\mathrm{p}<0.01)$. The lowest $\mathrm{pH}$ recorded was that of $\mathrm{T}_{2}$. The $\mathrm{pH}$ of all the media dropped from initial $\mathrm{pHs}$ of 4.7-6.6 to 4.4-4.7 after 42 days of cultivation depending on the treatments. The differences in the final $\mathrm{pH}$ were not significant. Reduction in $\mathrm{pH}$ in the organic based media is a common phenomenon and this is mainly associated with a poor buffering capacity of the soilless substrates to resist change in $\mathrm{pH}$ acidification of the medium by plant roots and use of acid fertilizers ${ }^{[4]}$. Although different plant species (and cultivars) have different $\mathrm{pH}$ range for optimal growth, overall the optimum $\mathrm{pH}$ of the soilless media for good availability of essential elements is around 6.0. Despite of low final $\mathrm{pHs}$ of the all media, observation revealed that the growth of plants was normal and did not show any elemental deficiency or toxicity symptoms.

The EC values of all media differed between treatments $(\mathrm{p}<0.0001)$, with $\mathrm{T}_{2}$ possessed the highest EC $\left(0.48 \mathrm{mS} \mathrm{cm}^{-1}\right)$ while both $\mathrm{T}_{4}$ and $\mathrm{T}_{5}$ had the lowest EC $\left(0.14 \mathrm{mS} \mathrm{cm}^{-1}\right)$. The ECs for other media were in the range of $0.16-0.2 \mathrm{mS} \mathrm{cm}^{-1}$. The $\mathrm{EC}$ values reflect the total inorganic ion concentration in the media extracts. Low EC value indicates that the media did not contain excessive salt that could cause salinity injury to the plants but, at the same time contains insufficient amount of nutrients to support healthy plant growth. Higher EC of $\mathrm{T}_{2}$ reflects that burnt rice hull contains relatively high concentration of soluble salts which could be beneficial for plant growth. As the acceptable range of initial EC of a good soilless media should be between $0.4-1.5 \mathrm{mS} \mathrm{cm}^{-1}$, the initial ECs of the media used have to be increased by adding fertilizer to give a quick supply of nutrients for early growth. The beneficial effects of increasing nutrients by directly incorporated slow released fertilizer into the cocopeat-based media on ornamental plants under Malaysian conditions were reported by Yahya and his co-researchers ${ }^{[29]}$.

Bulk density: Analysis of variance shows that bulk density of media differed significantly $(\mathrm{p}<0.05)$ among media (Table 1). Incorporation of $30 \%$ burnt rice hull into cocopeat $\left(\mathrm{T}_{2}\right)$ increased the bulk density of the media $\left(0.12 \mathrm{~g} \mathrm{~cm}^{-3}\right)$ and the value is significantly differed from other treatment. Result obtained here is inconsistent with resulted by Islam ${ }^{[10]}$ who found that the bulk density of loose rice husk charcoal (another name for burnt rice hull) was significantly lower than the bulk density of cocopeat. Differences in results obtained here is most likely due to the variation in particle-size distribution of the material ${ }^{[18]}$. Variability in the physical properties of soilless media is common $^{[27]}$. Results in Table 1 also indicated that addition of perlite and kenaf core fiber did not affect bulk density of cocopeat, although Webber et al. ${ }^{[26]}$ reported that amendment of various ratios of fine-grade kenaf to peat decreased the bulk density of media which lead to the increasing in its total porosity.

Bulk density affects the choice of media in many ways. Low bulk density media may be required for frequently irrigated greenhouse to avoid oxygen deficiency. Mixing and transportation of low bulk density media are much easier than those of high bulk density. However, media with a low bulk density may not provide adequate support for the plant and the plant may be top heavy ${ }^{[1]}$. In this respect plants grown in media containing burnt rice hull would be more stable.

Water retention: Water retention attributes the capability of a growing medium to retain water. Results pertaining to water retention characteristics of five growing media are shown in Fig. 1. Initially the volume of water held by different media was similar for all media as shown by non-significant F-test ( $p=0.0973)$. As the suction forces increased, the rate of water released significantly elevated leading to differences in the air content and available moisture from the media. The air content at the $1.0 \mathrm{kPa}$ were $17.7,27.9,25.0,12.8$ and $23.0 \%$, respectively, for $\mathrm{T}_{1}, \mathrm{~T}_{2}, \mathrm{~T}_{3}, \mathrm{~T}_{4}$ and $\mathrm{T}_{5}$. The volume of available water (volume of water released when suction increased from 1.0-10 kPa) differed among treatments with respective value of 54,61,36, 44 and $20 \%$ for $\mathrm{T}_{1}, \mathrm{~T}_{2}, \mathrm{~T}_{3}, \mathrm{~T}_{4}$ and $\mathrm{T}_{5}$ media. Verdonck et al. ${ }^{[24]}$ recommended that for optimal growth conditions, 30$45 \%$ of the water held in a root media should be easily available water. Differences in available water holding capacity among media could be due to their total porosity and types of pores ${ }^{[7]}$. Since differences in total porosity between media were not differed significantly (indicated by volume of water at $0.1 \mathrm{kPa}$ ), high available water recorded in media containing high proportion of cocopeat and cocopeat: Burnt rice hull was due to its high proportion of micropores (indicated by high volumetric water content at $1.0 \mathrm{kPa}$ suction, Fig. 1). 


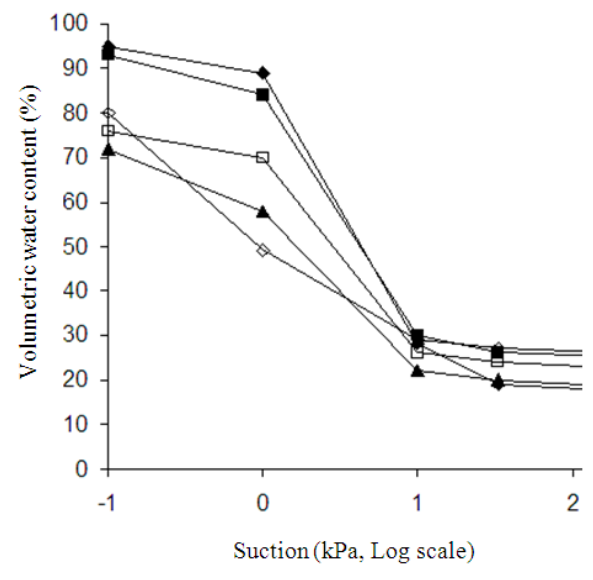

Fig. 1: Water retention curves of five combinations of media used in the study (Symbols: n: $-100 \%$ cocopeat; : $-70 \%$ cocopeat: $30 \%$ burnt rice hull; $\boldsymbol{\Delta}: 70 \%$ cocopeat: $30 \%$ perlite; $\square: 70 \%$ cocopeat: $30 \%$ kenaf core fiber; $\diamond:-40 \%$ cocopeat: $60 \%$ kenaf core fiber. Level of significance of F-test for mean values at respective at suction (log scale): $-1.0 \mathrm{kPa}(\mathrm{ns})$; $0 \mathrm{kPa},(\mathrm{p}<0.01) ; 1.0 \mathrm{kPa}(\mathrm{p}<0.05) ; 1.52 \mathrm{kPa}$ $(p<0.05) ;$ ns denotes not significant at $p<0.05$

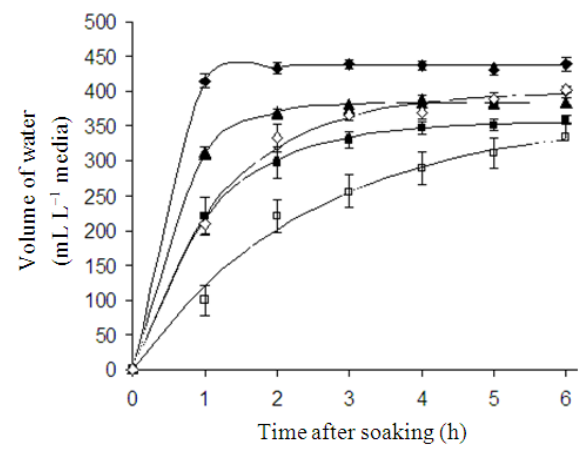

Fig. 2: Wettability in the form of $\mathrm{y}=\mathrm{A}\left(1-\mathrm{e}^{\mathrm{bx}}\right)$ of five media. Regression equations: $\mathbf{m}: \mathrm{y}=355.4$ (1$\left.\mathrm{e}^{0.936 \mathrm{x}}\right), \quad \mathrm{R}^{2}=0.99 ; \quad \forall: \quad \mathrm{y}=435.9 \quad\left(1-\mathrm{e}^{3.006 \mathrm{x}}\right)$, $\mathrm{R}^{2}=0.99 ; \boldsymbol{\Delta}: \mathrm{y}:=383.1\left(1-\mathrm{e}^{1.673 \mathrm{x}}\right), \mathrm{R}^{2}=0.99 ;$ 口: $y=364.1\left(1-e^{0.401 x}\right), R^{2}=0.97 ; \diamond: y=399.1$ $\left(1-\mathrm{e}^{0.798 x}\right), \mathrm{R}^{2}=0.97$

In contrast, low available water holding capacity in media containing high proportion of kenaf core fiber is linked to high proportion of large pores, in which much of the water is lost by gravity, as shown by rapid depletion of its moisture content. Loss of water through gravity forces can be reduced if finer particle of kenaf core fiber is used. The average particle size of kenaf core fiber used was $2.0 \mathrm{~mm}$. Sambo et al. ${ }^{[20]}$ reported that media comprised of ground rice hull with smaller particle size have had smaller total pore space but it contained more available water content. Working with a mixture of pinebark: sand: brown coal mixtures, Richards et al ${ }^{[18]}$ found that exclusion of all pinebark particles greater than $2 \mathrm{~mm}$ improve total water, available water and days to wilting without creating unfavorable level of aeration.

Wettability: The capacity of each medium to absorb water is represented by its wettability. The wettability of a material determines its aptitude to rewet itself. It is particularly important property in the case of horticultural growing media since it determines initial water uptake of the substrate and their subsequent water movement following root water removal and evapotranspiration ${ }^{[14]}$. The wettability of the media differed significantly and behave differently over time course as indicated by significant interaction between media and duration of soaking $(\mathrm{p}<0.0001)$ (Fig. 2). The highest water absorbing capacity after $6 \mathrm{~h}$ occurred in $\mathrm{T}_{2}$ and this is followed by $\mathrm{T}_{3}$, with their respective values of 432.2 and $368.4 \mathrm{~mL}$. The high amount of water absorbed by these two media reflected the synergic effects of burnt rice hull and perlite when they were incorporated into cocopeat. Meanwhile, mixture of $40 \%$ cocopeat and $60 \%$ kenaf core fiber had the lowest moisture content at $6 \mathrm{~h}$ after soaking suggesting that this medium contained high proportion of macropores.

High amount of fiber residues in cocopeat may associate with low wettability in $\mathrm{T}_{1}$. Regression analysis of data revealed that increased in wettability or water absorption pattern by various media follow the general logistic exponential curve:

$$
y=A\left(1-e^{-b x}\right)
$$

Where:

$\mathrm{A}=$ The asymptotic value for moisture content in the media

$\mathrm{b}=\mathrm{A}$ constant

$\mathrm{x}=$ The time $(\mathrm{h})$

$\mathrm{e}=$ The natural $\log$ value $(2.71)$

Media $T_{2}$ and $T_{3}$ reached their asymptotic values within $2 \mathrm{~h}$ after 'sub-irrigation' indicating that these two media had higher rates of water absorption. This is reflected by higher ' $b$ ' values of 3.006 and 1.673 for $T_{2}$ and $T_{3}$ respectively. Incorporation of kenaf core fiber at two different proportions gave two distinctive effects on wettability. Media containing high proportion of kenaf core fiber $\left(\mathrm{T}_{5}\right)$ have a higher rate of water absorption $(b=0.798)$ and ended-up with a significantly 
higher moisture content than the medium with $70 \%$ cocopeat and 30 kenaf core fiber $\left(\mathrm{T}_{4}, \mathrm{~b}=0.401\right)$. High water absorption by this medium may be due the settling effect upon wetting which reduces column height and changes the distribution between the capillary and noncapillary pores ${ }^{[15]}$. In the process, small particles settle into large non-capillary pores located between the larger particles. The greatest amount of settling normally occurred when the components were mixed in equal volumes. Settling can be reduced by using components of similar size ${ }^{[2]}$. Apart from manipulating the proportion of capillary pores in the media, the wettability can be increased by the addition of wetting agents ${ }^{[5,23]}$ and inorganic aggregates such sand and perlite into media $^{[2,7,28]}$. However, high proportion of inorganic aggregates reduces the water holding capacity of the media $^{[2]}$ making the plants grown on them more susceptible to water stress.

Air-filled porosity: The percentage of air-filled porosity (AFP) of the five growing media is shown in Table 2. Media containing 70 cocopeat: 30 burnt rice hull, 70 cocopeat: $30, \mathrm{v} / \mathrm{v}$ ) and $40 \%$ cocopeat: $60 \%$ kenaf core fiber had significantly higher AFP than the AFP of 100 cocopeat and 70 cocopeat: $30 \%$ kenaf core fiber. Except for $\mathrm{T}_{5}$, results in Table 2 show that prolonging duration of drainage from two to $5 \mathrm{~h}$ did not affect the AFP status of the media, indicating that the abilities of the media $T_{1}, T_{2}, T_{3}$ and $T_{4}$ to retain moisture against the gravity were similar.

Aeration depends mainly on the size of pores in a medium. Irrigating media to the point of saturation fills the total pore space with water. As the media drains by the force of gravity, smaller pores remain filled with water while larger pores emptied and fill with air. However, materials with small particles such as cocopeat tend to fill up the pores, thus lowering the AFP. Increasing the proportion of larger pores allows more aeration after drainage has stopped ${ }^{[9]}$. In this study, medium containing $70 \%$ cocopeat and $30 \%$ kenaf core fiber $\left(\mathrm{T}_{4}\right)$ had the lowest AFP. Lower AFP of $\mathrm{T}_{4}$ compared to medium with $40 \%$ cocopeat and $60 \%$ kenaf core fiber could be associated with the settling effect of the media component as discussed earlier.
Considering together with results observed on wettability, $\mathrm{T}_{5}$ could be wetted easily but the water in the medium would drain rapidly after irrigation and therefore plants grown on them must be watered more frequently otherwise they may be subjected to water deficit easily.

Plant growth and flowering: Differences in media markedly affected the growth and flowering performance of Celosia cristata (Table 3). At day 42 after transplanting, the height of plants grown on $\mathrm{T}_{1}, \mathrm{~T}_{2}, \mathrm{~T}_{3}$ and $\mathrm{T}_{4}$ were similar $\left(59.35-66.65 \mathrm{~cm}, \mathrm{LSD}_{0.05}=8.97 \mathrm{~cm}\right)$, but these plants were significantly taller than those grown in $\mathrm{T}_{5}(\mathrm{p}<0.01)$. Poor performance of plants grown on kenaf fiber containing media was also reported earlier by Webber et al. ${ }^{[26]}$ who found that plant height and shoot and root dry weights of Vinca minor decreased as the percentage of kenaf increased. Similar effects of increasing proportion of kenaf core fiber were detected for canopy diameter, leaf number and leaf area.

Results in Table 3 show that variation in media composition did not affect the number of days required to flowering significantly. All plants began to produce flower buds at 18-20 days after transplanting. However, variation in media significantly affected flower size as measured by the flower length. As other vegetative parameters, flowers produced by plants grown on $T_{5}$ were shorter.

Table 2: Air-filled porosity (AFP) of the mixtures at 2 and $5 \mathrm{~h}$ after drainage

\begin{tabular}{lll}
\hline Media $(\%)$ & $\begin{array}{l}\text { Hours } \\
\text { after soaking }\end{array}$ & $\begin{array}{c}\text { Air-filled } \\
\text { porosity }(\%)\end{array}$ \\
\hline 100 cocopeat $\left(\mathrm{T}_{1}\right)$ & 2 & $28.1 \mathrm{c}$ \\
& 5 & $29.8 \mathrm{c}$ \\
70 cocopeat: 30 burnt rice hull $\left(\mathrm{T}_{2}\right)$ & 2 & $38.0 \mathrm{~b}$ \\
70 cocopeat: 30 perlite $\left(\mathrm{T}_{3}\right)$ & 5 & $36.9 \mathrm{~b}$ \\
& 2 & $37.4 \mathrm{~b}$ \\
70 cocopeat: 30 kenaf core fiber $\left(\mathrm{T}_{4}\right)$ & 5 & $37.4 \mathrm{~b}$ \\
& 2 & $24.5 \mathrm{~d}$ \\
40 cocopeat: 60 kenaf core fiber $\left(\mathrm{T}_{5}\right)$ & 2 & $25.3 \mathrm{~d}$ \\
& 5 & $35.9 \mathrm{~b}$ \\
LSD & 5.05 & $43.2 \mathrm{a}$ \\
\hline
\end{tabular}

Values in each column with same letter did not differ significantly at $\mathrm{p}<0.05$ according to LSD

Table 3: Effects of media on growth and flowering of Celosia cristata at 42 days after transplanting

\begin{tabular}{|c|c|c|c|c|c|c|}
\hline Media (\%) & $\begin{array}{l}\text { Plant } \\
\text { height }(\mathrm{cm})\end{array}$ & $\begin{array}{l}\text { Canopy } \\
\text { diameter }(\mathrm{cm})\end{array}$ & Leaf no. & $\begin{array}{l}\text { Leaf area } \\
\left(\mathrm{cm}^{2}\right)\end{array}$ & $\begin{array}{l}\text { Flower } \\
\text { length }(\mathrm{cm})\end{array}$ & $\begin{array}{l}\text { Days to } \\
\text { flowering }\end{array}$ \\
\hline 100 cocopeat $\left(\mathrm{T}_{1}\right)$ & $64.27 \mathrm{a}$ & $26.70 \mathrm{a}$ & $52.0 \mathrm{ab}$ & $410.0 \mathrm{a}$ & $5.53 \mathrm{a}$ & $18.5 \mathrm{a}$ \\
\hline 70 cocopeat: 30 burnt rice hull $\left(\mathrm{T}_{2}\right)$ & $66.65 a$ & $26.47 \mathrm{a}$ & $55.0 \mathrm{a}$ & $463.31 \mathrm{a}$ & $5.49 \mathrm{a}$ & $19.7 \mathrm{a}$ \\
\hline 70 cocopeat: 30 perlite $\left(T_{3}\right)$ & $60.05 \mathrm{a}$ & $27.60 \mathrm{a}$ & $50.5 \mathrm{ab}$ & $362.51 \mathrm{ab}$ & $5.30 \mathrm{a}$ & $19.7 \mathrm{a}$ \\
\hline 70 cocopeat: 30 kenaf core fiber $\left(\mathrm{T}_{4}\right)$ & $59.35 \mathrm{a}$ & $27.17 \mathrm{a}$ & $45.5 b$ & $366.02 \mathrm{a}$ & $5.21 \mathrm{a}$ & $19.2 \mathrm{a}$ \\
\hline 40 cocopeat: 60 kenaf core fiber $\left(\mathrm{T}_{5}\right)$ & $41.53 b$ & $23.12 b$ & $31.7 \mathrm{c}$ & $239.33 b$ & $4.35 b$ & $19.7 \mathrm{a}$ \\
\hline $\mathrm{LSD}_{0.05}$ & 8.97 & 2.45 & 7.85 & 125.14 & 0.68 & 2.21 \\
\hline
\end{tabular}

Values in column with same letter did not differ significantly at $\mathrm{p}<0.05$ according to LSD 
Am. J. Agri. \& Biol. Sci., 4 (1): 63-71, 2009

Table 4: Effects of media on dry weight of vegetative and flower components of Celosia cristata at 42 days after transplanting

\begin{tabular}{lllll}
\hline & \multicolumn{4}{c}{ Dry weight $(\mathrm{g})$} \\
& ------------------ \\
Media $(\%)$ & Flower & Leaves & Stem & Roots \\
\hline 100 cocopeat $\left(\mathrm{T}_{1}\right)$ & $2.33 \mathrm{a}$ & $1.81 \mathrm{ab}$ & $1.95 \mathrm{ab}$ & $0.65 \mathrm{~b}$ \\
70 cocopeat: 30 burnt & $2.74 \mathrm{a}$ & $1.97 \mathrm{a}$ & $2.20 \mathrm{a}$ & $0.82 \mathrm{a}$ \\
rice hull $\left(\mathrm{T}_{2}\right)$ & & & & \\
70 cocopeat: 30 perlite & $2.43 \mathrm{a}$ & $1.54 \mathrm{~b}$ & $1.75 \mathrm{~b}$ & $0.74 \mathrm{ab}$ \\
$\begin{array}{l}\left(\mathrm{T}_{3}\right) \\
70 \text { cocopeat: } 30 \text { kenaf core }\end{array}$ & $2.25 \mathrm{a}$ & $1.75 \mathrm{ab}$ & $1.71 \mathrm{~b}$ & $0.64 \mathrm{~b}$ \\
fiber $\left(\mathrm{T}_{4}\right)$ & & & & \\
40 cocopeat: 60 kenaf core & $1.17 \mathrm{~b}$ & $0.97 \mathrm{c}$ & $0.94 \mathrm{c}$ & $0.37 \mathrm{c}$ \\
$\begin{array}{l}\text { fiber }\left(\mathrm{T}_{5}\right) \\
\mathrm{LSD}_{0.05}\end{array}$ & 0.62 & 0.34 & 0.36 & 0.16 \\
\hline $\begin{array}{l}\text { Values in column with } \\
\mathrm{p}<0.05 \text { according to LSD }\end{array}$ & & & &
\end{tabular}

The effects of various combinations of cocopeatbased media on dry weights of plant components are shown in Table 4. Overall, plants grown on $\mathrm{T}_{2}$ were the heaviest and this is mainly associated with their leaf, stem and root dry weights. However, stem dry weight of $\mathrm{T}_{2}$ did not significantly differ from the stem dry weight of plants grown on $T_{1}$. Results also indicated that leaf dry weight of plants grown on $\mathrm{T}_{1}, \mathrm{~T}_{2}$ and $\mathrm{T}_{4}$ were similar. Among the treatments, roots of plants grown on $T_{2}$ and $T_{3}$ were significantly heavier than the roots of other plants. Good root growth of plants grown on $T_{2}$ and $T_{3}$ could be attributed to the greater water availability and favorable aeration following the incorporation of burnt rice hull and perlite into cocopeat. Under such condition, plants were provided with sufficient water and oxygen Beside water availability and aeration, better root initiation and development could also be due to darker environment provided by burnt rice hull. Darker rhizosphere environment was reported to promote translocation and accumulation of auxin at the basal part of the plant thus a faster cell division and differentiation for root formation ${ }^{[5]}$. Despite of differences in dry weight of for cell respiration during the rooting process. inducing growth components, dry weights of flower for $T_{1}, T_{2}, T_{3}$ and $T_{4}$ were not significantly differed.

Plants grown on medium containing $40 \%$ cocopeat and $60 \%$ kenaf core fiber were the lightest with their overall dry weight was only $44.6 \%$ of those produced on $\mathrm{T}_{2}$. Poor growth performance of plants grown on media containing kenaf core fiber was also reported occurred in a range of crops, e.g., Vinca minor ${ }^{[26]}$ and Pinus halepensis seedlings ${ }^{[22]}$. Tsakaldimi $^{[22]}$ postulated that poor growth of Pinus halepensis seedlings on kenaf containing media was associated with high rate of kenaf decomposition which resulted in the shrinkage of its volume and this phenomenon is not favorable for plant growth.
Table 5: Effects of media on leaf nutrient contents (\%) of Celosia cristata

\begin{tabular}{llllll}
\hline & \multicolumn{3}{l}{ Nitrogen Phosphorus } & \multicolumn{3}{c}{ Potassium } & Calcium \\
Media $(\%)$ & $(\mathrm{N})$ & $(\mathrm{P})$ & $(\mathrm{K})$ & $(\mathrm{Ca})$ & $(\mathrm{Mg})$ \\
\hline 100 cocopeat $\left(\mathrm{T}_{1}\right)$ & 3.37 & 0.41 & 2.25 & 2.64 & 0.52 \\
70 Cocopeat: 30 & 2.85 & 0.40 & 1.73 & 2.61 & 0.58 \\
$\begin{array}{l}\text { burnt rice hull }\left(\mathrm{T}_{2}\right) \\
70 \text { cocopeat: } 30\end{array}$ & 2.95 & 0.42 & 1.99 & 2.78 & 0.54 \\
$\begin{array}{l}\text { perlite }\left(\mathrm{T}_{3}\right) \\
70 \text { cocopeat: } 30\end{array}$ & 3.13 & 0.32 & 2.36 & 2.53 & 0.58 \\
$\begin{array}{l}\text { kenaf core fiber }\left(\mathrm{T}_{4}\right) \\
40 \text { cocopeat: } 60\end{array}$ & 3.24 & 0.35 & 2.18 & 2.45 & 0.60 \\
$\begin{array}{l}\text { kenaf core fiber }\left(\mathrm{T}_{5}\right) \\
\text { f-test }\end{array}$ & $\mathrm{ns}$ & $\mathrm{ns}$ & $\mathrm{ns}$ & $\mathrm{ns}$ & $\mathrm{ns}$ \\
\hline
\end{tabular}

ns: Not Significant at $\mathrm{p}<0.05$

However, Wang ${ }^{[25]}$ found that Hibiscus rosa-chinensis and Brassia actinophylla established on kenaf-based media had similar or even higher fresh weight than those planted on commercial media.

Table 5 shows the effect of different cocopeatbased growing media on selected macronutrients contents in Celosia cristata leaves. Different combinations of media did not give significant effects on leaf nutrient contents. The compositions of nutrients recorded in this study were in the normal range found in healthy mature leaf tissue for various plant species ${ }^{[12]}$. As the leaf $\mathrm{N}, \mathrm{P}, \mathrm{K}, \mathrm{Ca}$ and $\mathrm{Mg}$ were not affected by the treatments, variation in the growth and flowering of Celosia cristata observed in this study were mainly linked with the differences in the physical properties of the media, especially with water availability and AFP. The importance of physical properties of media as the factor in determining plant development in soilless media was inline with the results published earlier ${ }^{[8,13,14\}}$.

\section{CONCLUSION}

In conclusion, results of this study indicated that certain chemical and physical properties of cocopeat can be improved through incorporation of burnt rice hull. The positive effects of burnt rice hull were seen in the elevation of nutrient availability (as indicated by higher EC), increased bulk density, air-filled porosity, available water and wettability. Improvement in chemical and physical properties following incorporation of burnt rice hull into cocopeat was reflected in a better plant growth. Although addition of kenaf core fiber did not improve physical characteristics of cocopeat-kenaf core mixtures, their physical properties especially water retention capacity could be improved by adding wetting agent and manipulating their particle size. 


\section{REFERENCES}

1. Abad, M., P. Noguera, R. Puchades, A. Maquieira and V. Noguera, 2002. Physico-chemical and chemical properties of some coconut dusts for use as a peat substitute for containerized ornamental plants. Biores. Technol., 82: 241-245. http://cat.inist.fr/?aModele $=$ afficheN\&cpsidt $=1355$ 1255

2. Argo, W.R., 1998. Root medium physical properties. HortTechnology, 8: 481-485. http://www.fao.org/agris/search/display.do?f=./199 9/v2502/US1997089441.xml;US1997089441

3. Argo, W.R., 1998. Root medium chemical properties. HortTechnology, 8: 846-894.

4. Argo, W.R. and P.R. Fisher, 2008. Understanding plant nutrition: Managing media $\mathrm{pH}$. Greenhouse grower.

http://www.greenhousegrower.com/magazine/?stor yid $=1495$

5. Bilderback, T.E. and M.R. Lorscheider, 1997. Wetting agent used in container substrate are they BMP's? Acta Hortic., 450: 313-319. http://www.fao.org/agris/search/display.do?f=./199 9/v2502/US1997089442.xml;US1997089442

6. Budiarto, K.Y., E.S.N. Sulyo and R.H.M. Maaswinkel, 2006. Effects of types of media and NPK fertilizer on the rooting capacity of chrysanthemum cuttings. Indonesian J. Agric. Sci., 7: 67-70.

http://www.kennisonline.wur.nl/NR/rdonlyres/DFE 5D50E-A530-48F6-9660-

63421045384B/40815/effectsmediaandnpk.pdf

7. Bunt, A.C., 1988. Media and Mixes for ContainerGrown Plants. 1st Edn., Springer, London, ISBN: 10: 0046350160

8. Chavez, W., A.D. Benedetto, G. Civeira and R. Lavado, 2008. Alternative soilless media for growing Petunia $x$ hybrida and Impatiens wallerana: Physical behavior, effect of fertilization and nitrate losses. Biores. Technol., 99: 8082-8087. http://cat.inist.fr/?aModele $=$ afficheN\&cpsidt $=2058$ 8591

9. Handreck, K.A. and N.D. Black, 2007. Growing Media for Ornamental Plants and Turf. 3rd Edn., UNSW Press, Sydney, ISBN:13:9780868407968

10. Islam, S., 2008. Evaluating performance of ecologically sound organic substrates under different temperature regimes. Int. J. Agric. Biol., 10: 297-300. http://www.fspublishers.org/ijab/pastissues/IJABVOL_10_NO_3/11.pdf

11. Holcomb, E.J., 1994. Growing Media. 4th Edn., Ball Publishing, Batavia, Ill, ISBN: 188305205-X.
12. Jobin, P., J. Caron, P. Bernier and B. Dansereau, 2004. Impact of two hydrophilic acrylic-based polymers on the physical properties of three substrates and the growth of Petunia $x$ hybrid brilliant pink. J. Am. Soc. Hortic. Sci., 129: 449. (Abstr.)

http://journal.ashspublications.org/cgi/content/abstr act/129/3/44912

13. Karla, Y.P., 1998. Handbook of Reference Methods for Plant Analysis. 3rd Edn., CRC Press, Boca Raton, Fl., ISBN: 13: 9781574441246.

14. Michel, J.C., L.M. Riviere and M.N. Fontaine, 2001. Physical properties of peat: A key factor in their use as growing media. Eur. J. Soil Sci., 52: 1-7. http://www.poletourbieres.org/docs/Lamoura_Michel_eng.pdf

15. Nash, M.A. and F.A. Pokorny, 1990. Shrinkage of selected two-component container media. HortScience, 28: 930-931. http://cat.inist.fr/?aModele $=$ afficheN\&cpsidt $=19605747$

16. Paradiso, R. and S. De Pascale, 2008. Effects of coco fiber addition to perlite on growth and yield of cut gerbera. Acta Hortic., 779: 529-534. http://direct.bl.uk/bld/PlaceOrder.do?UIN=228787 $500 \&$ ETOC $=$ RN \& from $=$ searchengine

17. Reichert, N.A. and B.S. Baldwin, 1996. Growth of Bedding Plants in a Kenaf-Based Potting Medium. In: Progress in New Crops, Janick, J. (Ed.). ASHS Press, Arlington, VA., pp: 411-414. http://www.hort.purdue.edu/newcrop/proceedings1 996/v3-411.html

18. Richards, D.M.L. and D.V. Beardsell, 1986. The influence of particle-size distribution in pinebark:sand: Brown coal potting mixes on water supply, aeration and plant growth. Sci. Hortic., 29: 1-14.

http://cat.inist.fr/?aModele $=$ afficheN\&cpsidt $=8016570$

19. Robbins, J.A. and M.R. Evans, 2004. Growing media for container production in a greenhouse or nurseries. Part 1: Components and mixes. Agriculture and Natural Resources. Division of Agriculture: University of Arkansas, Fayetteville. http://www.uaex.edu/Other_Areas/publications/PD F/FSA-6097.pdf

20. Sambo, P., F. Sannazzaro and M.R. Evans, 2008. Physical properties of ground fresh rice hulls and sphagnum peat used for greenhouse root substrates. HortTechnology, $18: \quad 384 . \quad$ (Abstr.) http://horttech.ashspublications.org/cgi/content/abs tract $/ 18 / 3 / 384$ ? maxtoshow $=\&$ HITS $=10 \&$ hits $=10 \&$ RESULTFORMAT $=\&$ author $1=$ Sambo\&fulltext $=\mathrm{fr}$ esh+rice+hull\&searchid=1\&FIRSTINDEX=0\&sort spec $=$ relevance $\&$ resourcetype $=$ HWCIT 
21. Teh, C.B.S. and T. Jamal, 2006. Bulk Density, Water Content, Porosity and Water Retention. In: Soil Physic Analyses, University Putra Malaysia Press, Selangor, Malaysia, pp: 11-17.

22. Tsakaldimi, M., 2006. Kenaf (Hibiscus cannabinus L.) core and rice hulls as components of container media for growing Pinus halepensis M. seedlings. Biores. Technol., 97: 1631-1639. http://cat.inist.fr/?aModele $=$ afficheN\&cpsidt $=1788$ 0015

23. Urrestarazu, M., C. Guillen, P.C. Mazuela and G. Carrasco, 2008. Wetting agent effect on physical properties of new and reused rockwool and coconut coir waste. Sci. Hortic., 116: 104-108. http://cat.inist.fr/?aModele $=$ afficheN\&cpsidt $=2015$ 7781

24. Verdonck, O., R. Penninck and M. De Boodt, 1983. The physical properties of different horticultural substrates. Acta Hortic., 150: 155-160. http://www.fao.org/agris/search/display.do?f=./198 7/v1311/NL8701096.xml;NL8701096

25. Wang, Y.T., 1994. Using ground kenaf stem core as a major component of container media. J. Am. Soc. Hortic. Sci., 119: 931-935. http://cat.inist.fr/?aModele $=$ afficheN\&cpsidt $=11251658$
26. Webber, C.L., J. Whitworth and J. Dole, 1999. Kenaf (Hibiscus cannabinus L.) core as a containerized growth medium component. Ind. Crops Prod., 10: 97-105. DOI: 10.1016/S09266690(99)00014-X

27. Wiberg, A., R. Koenig and T. Cerny-Koenig, 2005. Variability in the physical and chemical properties of retail potting media. HortTech., 15: 752-757. http://direct.bl.uk/bld/PlaceOrder.do?UIN=177287 $323 \& E T O C=R N \&$ from $=$ searchengine

28. Yahya, A., H. Safie and S. Kahar, 1997. Properties of cocopeat-based growing media and their effects on two annual ornamentals. J. Trop. Agric. Food Sci., 25: 151-157.

http://direct.bl.uk/bld/PlaceOrder.do?UIN=055801 873\&ETOC $=$ RN\& from $=$ searchengine

29. Yahya, A., H. Safie and M.S. Mohklas, 1999. Growth and flowering responses of potted chrysanthemum in a coir dust-based medium to different rates of slow released-fertilizer. J. Trop. Agric. Food Sci., 27: 39-46. http://direct.bl.uk/bld/PlaceOrder.do?UIN=109629 $923 \&$ ETOC $=$ RN\& from=searchengine 